\title{
COMMENTARY
}

\section{Did the Atlantic close and then reopen?: A commentary}

\author{
Harold (Hank) Williams* \\ Department of Earth Sciences \\ Memorial University \\ St. John's, Newfoundland and Labrador, A1B 3X5, Canada \\ *Passed away September 28, 2010.
}

Tuzo Wilson's 1966 Nature paper entitled "Did the Atlantic close and then re-open?" is truly the major turning point in the history of ideas on the evolution of the Appalachian Orogen. For a hundred years, the Appalachian Orogen was the type geosyncline, and Appalachian evolution was viewed in fixist models of geosynclinal development. Contrasting faunal realms were always enigmatic and never properly explained by notions of land barriers. Equally enigmatic was the symmetry and two-sided nature of the Newfoundland cross-section that refuted the fixist idea that continents grew like trees by the outward addition of asymmetric peripheral rings. The Wilson Cycle of closing a proto-Atlantic Ocean, then re-opening the Atlantic Ocean provided an elegant and simple solution to these enigmas.

Wilson realized that island arcs existed on the North American side of the proto-Atlantic, such as the present Notre Dame Subzone in Newfoundland, and that the major faunal boundary lay to the east of these volcanic rocks. He also realized that the early Paleozoic continents may have touched in the middle Ordovician, "...for thereafter the distinction between the Atlantic and Pacific faunal realms ceases to be marked." One continent encroaching upon another in the middle and late Ordovician explained the former borderland concept of Charles Schuchert and Marshall Kay. Likewise, Kay's island arcs were most in evidence during the early Ordovician, the time of major proto-Atlantic closing.

Wilson also recognized irregularities in ocean closing, which occurs first at promontories, then at re-entrants, with resulting clastic wedges, and an overall change from early Paleozoic marine conditions to middle and late Paleozoic terrestrial conditions. The Taconic allochthons were also part of his ocean closing scenario. The proto-Atlantic was completely closed by the end of the Paleozoic, and major spreading of the Atlantic began in the Cretaceous.
Wilson then went on to trace the former course of the proto-Atlantic along the length of the Appalachian-Caledonian chain from Spitsbergen to Florida. This is no small task. It is encouraging to see that the contemporary Newfoundland analysis supported his views, and that even Tuzo had trouble finding a suture along the New England segment of the system. Northwest Africa was accommodated with ease as a Hercynian orogenic belt, in some respects symmetrical to the southern Appalachians.

An important corollary of the Wilson Cycle is that the assembly and eventual breakup of Pangaea must have been an event of major significance in world geology. This is certainly true in North America, where major orogenesis and accretion in the Cordilleran Orogen on the Pacific Margin corresponds to Atlantic opening.

Since the 1966 Wilson paper, we have emerged from fixist geosynclinal models that were entrenched in the literature for 100 years. Still, the Appalachian Orogen is full of surprises and there are many secrets yet to be revealed. As so aptly expressed by David Baird, how strange it is that the more we seem to find out, the horizon is still there, always inviting us to go closer. We have more problems now than our predecessors, before the advent of the Wilson Cycle. And where will the horizon be teasing us to approach in 25 or 50 or the next 100 years? Will we be then as far away from where we stand now as our present position is from the world of pre-Wilson Cycle practitioners?

\section{Editor's Note}

Hank wrote this eloquent commentary for a local conference held in St. John's in early 1992, to mark the $25^{\text {th }}$ anniversary of Tuzo Wilson's landmark paper. Tuzo himself was of course the guest of honour. Those of us who were involved in the event remember it well, and a diverse assortment of guest speakers gave their own perspectives on the paper, and its influence upon later work in the Appalachians and elsewhere. I had actually forgotten about Hank's commentary until I found the 1992 conference program whilst fruitlessly searching for another document. After reading it again, it seemed only appropriate to include it here and provide it wider circulation. The current executive of the Newfoundland Section of GAC are thanked for giving permission to reprint a short piece that surely will demonstrate longevity.

Andrew Kerr 